\title{
Comparative study of virulence factors among methicillin resistant Staphylococcus aureus clinical isolates
}

\author{
Ons Haddad ${ }^{1,2^{*}}$ D , Abderrahmen Merghni ${ }^{2}$, Aida Elargoubi ${ }^{1,2}$, Hajer Rhim ${ }^{1,2}$, Yosr Kadri $^{1,2}$ and Maha Mastouri ${ }^{1,2}$
}

\begin{abstract}
Background: Methicillin resistant Staphylococcus aureus (MRSA) is recognized worldwide as a leading cause of hospital and community infections. Biofilm formation by MRSA is an extremely important virulence factor to be understood. Our aim was to establish phenotypic and genotypic characterization of virulence factors among 43 MRSA clinical isolates in a Tunisian hospital.
\end{abstract}

Methods: We investigated enzymatic profiles, biofilm production and prevalences of genes encoding intracellular adhesion molecules (icaA and icaD), Microbial Surface Components Recognizing Adhesive Matrix Molecules genes (fnbA, fnbB and cna) and exoenzymes genes (geh, sspA and sspB).

Results: Our findings revealed that caseinase, gelatinase, lipase and lecithinase activities were detected in 100\%, 100\%, $76.6 \%$ and $93.3 \%$ of cases respectively. This study showed that 23 strains (76.7\%) were slime producers on Congo red medium. Furthermore, $46.5 \%$ and $53.5 \%$ of isolates were respectively highly and moderately biofilm-forming on polystyrene. Significant association was found between both biofilm tests. PCR detection showed that $74.4 \%, 18.6 \%$, $69.8 \%, 65.1 \%$ and $74.4 \%$ of isolates harbored $f n b A, f n b B$, icaA, icaD and cna genes respectively. In addition, 34.9\%, 18.6\% and $30.2 \%$ of MRSA strains were found positive for $s 5 p A, s s p B$ and geh genes respectively. Further, statistical data showed that the presence of the $f n b A$ and $f n b B$ genes was significantly associated with a high biofilm production on polystyrene. However, no statistical association was observed for the icaA, icaD and cna genes.

Conclusions: This study indicates that the detection of $f_{n} b A$ and $f n b B$ contributing to the first step of biofilm formation has been predictable of high biofilm production. As studied factors contribute to MRSA virulence, this research could be of value in orienting towards the development of new preventive and therapeutic measures.

Keywords: Staphylococcus aureus, methicillin, biofilm, virulence, adhesion molecules

\section{Introduction}

Methicillin resistant Staphylococcus aureus (MRSA) is recognized worldwide as an important bacterial pathogen causing a wide range of infections ranging from skin and soft tissue lesions to lethal infections (osteomyelitis, endocarditis, pneumonia and septicaemia). It is regarded as a major world health threat with a substantial increase in morbidity and mortality [1]. In addition to resistance, the pathogenicity of MRSA is an extremely

\footnotetext{
* Correspondence: onshadad@gmail.com

'Laboratoire de Microbiologie, CHU Fatouma Bourguiba de Monastir, Monastir, Tunisie

${ }^{2}$ Laboratoire des Maladies Transmissible et Substances Biologiquement Actives, LR99ES27, Faculté de Pharmacie de Monastir, Université de Monastir, Monastir, Tunisie
}

important feature to be understood. The pathogenesis of this bacterium depends on a combination of extracellular factors and biofilm forming ability [2]. The adherence of $S$. aureus to biotic and abiotic surfaces stage is mediated by a protein family of staphylococcal Microbial Surface Components Recognizing Adhesive Matrix Molecules (MSCRAMMs). Whereas the cell aggregation is led by the synthesis of polysaccharide intercellular adhesin (PIA) molecule encoded by the intracellular adhesion (ica) [3-6].

Our aim was to establish a phenotypic characterization of virulence factors among MRSA clinical isolates in a Tunisian Hospital, to determine prevalences of genes encoding intracellular adhesion molecules (icaA and icaD), 
MSCRAMMs genes (fnbA, fnbB, cna) and exoenzymes genes (geh, $s s p A$ and $\operatorname{ssp} B$ ), and to investigate the involvement of these genes in biofilm forming ability.

\section{Materials and methods}

\section{Bacterial strains}

A total of 43 non-redundant MRSA clinical isolates were obtained from the Laboratory of Microbiology of the University hospital of Monastir-Tunisia. These strains were obtained from bacteriological samples in hospitalized patients and/or consultants at the University Hospital of Monastir-Tunisia during the period (January 2016 - June 2016). Two reference strains (S. aureus ATCC 6538 and ATCC 43300) were used as controls. Bacterial identification was performed using Gram staining, catalase test, tube coagulase, DNase agar, mannitol salt agar and API ID 20 STAPH galleries (bio-Merieux, France). To confirm the identity of the isolate as $S$. aureus, the Sa442 gene was amplified by a PCR-based method. Extraction of genomic DNA was performed using a standard phenolechloroform technique. The PCR mixture $(25 \mu \mathrm{l})$ for all genes contained $1 \mathrm{mM}$ forward and reverse primers, dNTP mix (100 mM each of dATP, dCTP, dGTP and dTTP), 1 U of Go Taq DNA polymerase (Promega), $5 \mathrm{ml}$ green Go Taq buffer (5X), and DNA template $(50 \mathrm{ng})$. PCR conditions were the following: an initial temperature of $96^{\circ} \mathrm{C}(3 \mathrm{~min})$, followed by denaturation at $95^{\circ} \mathrm{C}(1 \mathrm{~min})$, annealing at $55^{\circ} \mathrm{C}(30 \mathrm{~s})$, elongation at $72^{\circ} \mathrm{C}(3 \mathrm{~min})$, and a final elongation step at $72^{\circ} \mathrm{C}$ (4min). Amplicons of the expected size (108 bp) were obtained. Methicillin resistance was confirmed using a cefoxitin disk $(30 \mu \mathrm{g})$ on Mueller-Hinton agar plates (Bio-Rad, France) as recommended by the French Society of Microbiology and by the European Committee on Antimicrobial Susceptibility Testing. The mecA gene was detected by PCR. PCR conditions were the following : an initial temperature of $95^{\circ} \mathrm{C}(1 \mathrm{~min})$, denaturation at $95^{\circ} \mathrm{C}(15 \mathrm{~s})$, annealing at $45^{\circ} \mathrm{C}(15 \mathrm{~s})$, and elongation at $72^{\circ} \mathrm{C}$ (30s), with a final extension at $72^{\circ} \mathrm{C}(4 \mathrm{~min})$. Amplicons of the expected size (162 bp) were obtained [7]. PCR primers were chosen as listed in Table 1.

Amplified PCR products were analyzed on $2 \%(\mathrm{wt} / \mathrm{v})$ agarose gel stained with ethidium bromide $\left(0.5 \mu \mathrm{g} \mathrm{ml}{ }^{-1}\right)$, visualized under ultraviolet transillumination and photographed using Gel Doc XR apparatus (Biorad, USA).

\section{Characterization of the enzymatic activity}

The ability to produce hydrolytic enzymes was determined after inoculation of cultures on TSA-1 media (Biorad) supplemented with: $1 \%$ (wt/vol) skim milk for caseinase; 1\% (wt/vol) gelatin for gelatinase; Tween 80 for lipase and $5 \%$ (vol/vol) egg yolk for lecithinase. The presence of a clear halo around the colonies indicates the presence of the hydrolytic enzyme. The haemolytic activity was evaluated on bacteriological agar supplemented with $5 \%$ sheep's blood [8].

\section{Phenotypic determination of slime production}

Phenotypic qualitative characterization of slime producing strains was carried out by the cultivation of the

Table 1 List of primers used for bacterial identification and detection of MSCRAMMs genes (fnbA, fnbB and cna), biofim control genes (icaA and icaD) and exoenzymes genes (sspA, sspB and geh)

\begin{tabular}{|c|c|c|c|c|c|}
\hline Target gene & Sequence $\left(5^{\prime}-3^{\prime}\right)$ & $\mathrm{aT}\left({ }^{\circ} \mathrm{C}\right)$ & Amplified fragment & Amplicon size (bp) & Reference \\
\hline $5 a 442$ & $\begin{array}{l}\text { 5'-AATCTTTGTCGGTACACGATATTCTTCACG-3' } \\
\text { 5'-CGTAATGAGATTCAGTAAATACAACA-3' }\end{array}$ & 55 & Sa442 protein & 108 & [7] \\
\hline mecA & $\begin{array}{l}\text { 5'-ACCAGATTACAACTTCACCAGG-3' } \\
\text { 5'-CCACTTCATATCTTGTAACG-3' }\end{array}$ & 45 & Penicillin binding protein 2a & 162 & [7] \\
\hline$i c a A$ & $\begin{array}{l}\text { 5'-ACACTTGCTGGCGCAGTCAA-3' } \\
\text { 5'-TCTGGAACCAACATCCAACA-3' }\end{array}$ & 55 & Intercellular adhesion A & 188 & [24] \\
\hline$i c a D$ & $\begin{array}{l}\text { 5'-ATGGTCAAGCCCAGACAGAG-3' } \\
\text { 5'-AGTATTITCAATGTTIAAAGCAA-3' }\end{array}$ & 55 & Intercellular adhesion D & 198 & [24] \\
\hline Can & $\begin{array}{l}\text { 5'-GTCAAGCAGTTATTAACACCAGAC-3' } \\
\text { 5'-AATCAGTAATTGCACTTTGTCCACTG-3' }\end{array}$ & 62 & Collagen adhesion & 192 & [36] \\
\hline$f n b A$ & $\begin{array}{l}\text { 5'-CATAAATTGGGAGCAGCATCA-3' } \\
\text { 5'-ATCAGCAGCTGAATTCCCATT-3' }\end{array}$ & 62 & Fibronectin binding protein A & 191 & [36] \\
\hline$f n b B$ & $\begin{array}{l}\text { 5'-GTAACAGCTAATGGTCGAATTGATACT-3' } \\
\text { 5'-CAAGTTCGATAGGAGTACTATGTTC-3' }\end{array}$ & 62 & Fibronectin binding protein B & 201 & [36] \\
\hline $\operatorname{ssp} A$ & $\begin{array}{l}\text { 5'-GACAACAGCGACACTTGT 3' } \\
\text { 3'-AGTATCTTACCTACAACTACA-5' }\end{array}$ & 45 & Serine protease & 292 & [40] \\
\hline$s s p B$ & $\begin{array}{l}\text { 5'-TGAAGAAGATGGCAAAGTTAG-3' } \\
\text { 3'-TTGAGATACACTITGTGCAAG-5' }\end{array}$ & 47 & Cysteine protease & 493 & [40] \\
\hline Geh & 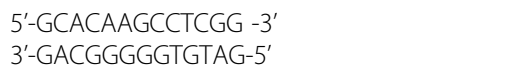 & 40 & Lipase & 473 & [45] \\
\hline
\end{tabular}


isolates on Congo red agar (CRA) plate made by mixing $36 \mathrm{~g}$ of sucrose (Sigma Chemical Company, St. Louis, $\mathrm{MO}$ ) with 0.8 Congo red in $1 \mathrm{~L}$ of brain heart infusion agar (Biorad, USA) as previously described [9]. The strains were incubated at $37^{\circ} \mathrm{C}$ for 24 hours under aerobic conditions followed by subsequent storage at room temperature. The Congo red dye interacts directly with certain bacterial polysaccharides forming a slime and giving black colonies in contrast to the non-producing colonies which remain red. After 48-72 hours, the results were interpreted as follows: strains producing intensive black, black, and reddish black colonies with a rough, dry, and crystalline consistency were classified as slime producers, whereas red and Bordeaux red with smooth colonies were considered to be non slime producers [9].

\section{Semi-quantitative adherence assay}

Biofilm production by MRSA strains, grown in Brain Heart Infusion with $1 \%$ glucose, was quantified using a semi-quantitative adherence assay on 96-well tissue culture plates as described previously [10]. Adherent bacteria were fixed with $95 \%$ ethanol and stained with $100 \mathrm{~mL}$ of $1 \%$ crystal violet (Merck, France) for $5 \mathrm{~min}$. The microplates were air-dried and the optical density of each well was measured at $570 \mathrm{~nm}$ (OD570) using an automated Multiskan reader (GIO. DE VITA E C, ome, Italy). This assay was performed for each strain in triplicate. The background was determined by using noninoculated media as a control. The cut-off value (ODC) of noninoculated media at an optical density of $570 \mathrm{~nm}$ (OD570) was considered the deadline point to define biofilm quantities [cut-off (ODC) $=$ mean OD +3 standard deviation (SD) of negative control]. Biofilm formation was interpreted as highly positive (OD570> $=4 *$ ODC), moderately positive $(2 *$ ODC $<=$ OD570 $<4 *$ ODC), weakly positive (ODC $<=$ OD570 $<2$ * ODC) or negative $(\mathrm{OD} 570<\mathrm{ODC})$. These criteria were established by Stepanovic et al. [11].

\section{Detection of icaA, icaD, fnbA, fnbB, cna, sspA, sspB and geh genes}

PCR primers were chosen as listed in Table 1. Amplifications of $i c a A, i c a D, f n b A, f n b B, c n a, \operatorname{ssp} A, \operatorname{ssp} B$ and geh genes were performed according to the following cycle conditions: an initial denaturation at $94^{\circ} \mathrm{C}$ for $5 \mathrm{~min}$ was followed by 30 cycles of denaturation at $94^{\circ} \mathrm{C}$ for $30 \mathrm{~s}$, annealing for $30 \mathrm{~s}$ at temperature determined for each gene as described in Table 1 and elongation at $72^{\circ} \mathrm{C}$ for $45 \mathrm{~s}$, followed by $10 \mathrm{~min}$ of final extension at $72^{\circ} \mathrm{C}$.

\section{Statistical analysis}

The data from this study were captured, recorded and analyzed by SPSS 17.0 software. The non-parametric
Mann Whitney U test was used to compare biofilm production assays (Congo red test and polystyrene adherence assay). The same statistical test was used to evaluate correlations of MSCRAMMs genes ( $f n b A, f n b B$ and cna), biofilm production control genes (icaA and $i c a D)$ and exoenzymes genes ( $s p A, \operatorname{ssp} B$ and geh) to the level of biofilm production on polystyrene. All factors with $\mathrm{p}$ values of less than 0.20 were included in multivariate ordinal logistic regression analysis. $P$ values of less than 0.05 were considered to indicate significant difference.

\section{Results}

\section{Distribution of isolates}

A total of 43 MRSA strains were collected (i.e. a rate of $21.4 \%$ of all S. aureus isolates in the laboratory of Microbiology at the University Hospital of Monastir-Tunisia during the same period). Samples were gathered from different organs and systems: pus (58.1\%), blood (25.6\%), respiratory samples $(11.6 \%)$ and catheters $(4.7 \%)$. They were collected from patients admitted in surgery units $(44.2 \%)$, intensive care units (25.6\%), medical units (13.9\%), Pediatrics/Neonatology (9.3\%) and Gynecology (7.0\%).

\section{Characterization of the enzymatic activity}

Our results showed that $51.1 \%$ and $48.9 \%$ of isolates were respectively beta and alpha-hemolytic. All isolates were protease producers (caseinase and gelatinase). Lipase and lecithinase secretion were found in 93.0\% and $79.1 \%$ of cases respectively (Table 2 ).

\section{Phenotypic determination of slime production}

Out of 43 MRSA isolates, 30 strains (69.8\%) were slime producers on the CRA plate. They were black or reddish black color colony producers. Slime production was noted in 16 out of 25 strains isolated from suppurations and in 9 out of 11 blood culture isolates (Table 3).

\section{Semi-quantitative adherence assay}

The results of OD570 presented in Table 3, showed that $46.5 \%$ and $53.5 \%$ strains were respectively highly and moderately biofilm-formers on polystyrene. No isolate was weakly or non-biofilm producer on polystyrene. We detected 5/11 blood culture isolates and 10/25 pus isolates considered as highly biofilm formers. Both reference strains S. aureus ATCC 6538 and ATCC 43300 were highly biofilm-forming on polystyrene.

\section{Detection by PCR of icaA, icaD, fnbA, fnbB, cna, sspA, ssp $B$ and geh genes}

The icaA and the icaD genes were present in $69.8 \%$ and $65.1 \%$ of MRSA isolates respectively. A concomitant presence of both genes was detected in $55.8 \%$ of the strains. Our results revealed that $74.4 \%$ and $18.6 \%$ of 
Table 2 Exoenzymes production and hemolysis of studied strains

\begin{tabular}{|c|c|c|c|c|c|}
\hline \multirow[t]{2}{*}{ Strains } & \multicolumn{4}{|c|}{ Exoenzymes expression } & \multirow[t]{2}{*}{ Hemolysis type } \\
\hline & Lecithinase & Lipase & Caseinase & $\overline{\text { Gelatinase }}$ & \\
\hline ATCC6538 & + & + & + & + & Beta \\
\hline 1 & + & + & + & + & Alpha \\
\hline 2 & + & + & + & + & Alpha \\
\hline 3 & + & + & + & + & Alpha \\
\hline 4 & + & + & + & + & Alpha \\
\hline 5 & + & + & + & + & Beta \\
\hline 6 & + & + & + & + & Beta \\
\hline 7 & + & + & + & + & Beta \\
\hline 8 & - & - & + & + & Beta \\
\hline 9 & + & + & + & + & Alpha \\
\hline 10 & + & + & + & + & Beta \\
\hline 11 & + & + & + & + & Alpha \\
\hline 12 & + & + & + & + & Beta \\
\hline 13 & + & + & + & + & Beta \\
\hline 14 & + & - & + & + & Alpha \\
\hline 15 & + & + & + & + & Alpha \\
\hline 16 & + & - & + & + & Beta \\
\hline 17 & + & - & + & + & Beta \\
\hline 18 & + & + & + & + & Alpha \\
\hline 19 & + & + & + & + & Beta \\
\hline 20 & + & + & + & + & Alpha \\
\hline 21 & + & + & + & + & Beta \\
\hline 22 & + & + & + & + & Alpha \\
\hline 23 & - & - & + & + & Beta \\
\hline 24 & + & + & + & + & Alpha \\
\hline 25 & + & + & + & + & Alpha \\
\hline 26 & + & + & + & + & Beta \\
\hline 27 & + & + & + & + & Beta \\
\hline 28 & + & + & + & + & Alpha \\
\hline 29 & + & + & + & + & Alpha \\
\hline 30 & - & - & + & + & Beta \\
\hline 31 & + & + & + & + & Beta \\
\hline 32 & + & + & + & + & Alpha \\
\hline 33 & + & + & + & + & Alpha \\
\hline 34 & + & + & + & + & Alpha \\
\hline 35 & + & + & + & + & Beta \\
\hline 36 & + & - & + & + & Alpha \\
\hline 37 & + & + & + & + & Beta \\
\hline 38 & + & + & + & + & Beta \\
\hline 39 & + & + & + & + & Alpha \\
\hline 40 & + & - & + & + & Beta \\
\hline 41 & + & + & + & + & Alpha \\
\hline 42 & + & + & + & + & Beta \\
\hline 43 & + & - & + & + & Beta \\
\hline$\%$ expression & $93,0 \%$ & $79,1 \%$ & $100 \%$ & $100 \%$ & 48.9\%(alpha);51.1\%(beta) \\
\hline
\end{tabular}


Table 3 Slime production and adherence assay of methicillin resistant Staphylococcus aureus isolates

\begin{tabular}{|c|c|c|c|}
\hline Strains & $\begin{array}{l}\text { Biofilm phenotype } \\
\text { (CRA) }\end{array}$ & $\mathrm{OD} 570 \pm \mathrm{SD}$ & Adherence state \\
\hline ATCC 6538 & S+ & $2.90 \pm 0.05$ & highly positive \\
\hline ATCC 43300 & S+ & $0.71 \pm 0.15$ & highly positive \\
\hline 1 & S- & $0.19 \pm 0.05$ & moderately positive \\
\hline 2 & S- & $0.12 \pm 0.03$ & moderately positive \\
\hline 3 & S+ & $0.13 \pm 0.02$ & moderately positive \\
\hline 4 & S+ & $0.59 \pm 0.11$ & highly positive \\
\hline 5 & S+ & $0.46 \pm 0.02$ & highly positive \\
\hline 6 & S+ & $0.26 \pm 0.01$ & highly positive \\
\hline 7 & S+ & $0.22 \pm 0.08$ & moderately positive \\
\hline 8 & S+ & $0.42 \pm 0.01$ & highly positive \\
\hline 9 & S- & $0.15 \pm 0.02$ & moderately positive \\
\hline 10 & S+ & $0.80 \pm 0.03$ & highly positive \\
\hline 11 & S+ & $2.96 \pm 0.08$ & highly positive \\
\hline 12 & S- & $0.15 \pm 0.04$ & moderately positive \\
\hline 13 & S- & $0.15 \pm 0.07$ & moderately positive \\
\hline 14 & S+ & $1.77 \pm 0.02$ & highly positive \\
\hline 15 & S+ & $0.22 \pm 0.01$ & moderately positive \\
\hline 16 & S+ & $0.17 \pm 0.03$ & moderately positive \\
\hline 17 & S+ & $2.62 \pm 0.01$ & highly positive \\
\hline 18 & S+ & $0.24 \pm 0.02$ & highly positive \\
\hline 19 & S+ & $0.13 \pm 0.05$ & moderately positive \\
\hline 20 & S+ & $0.62 \pm 0.03$ & highly positive \\
\hline 21 & S+ & $0.12 \pm 0.03$ & moderately positive \\
\hline 22 & S+ & $0.21 \pm 0.39$ & moderately positive \\
\hline 23 & S+ & $0.14 \pm 0.06$ & moderately positive \\
\hline 24 & S+ & $0.14 \pm 0.01$ & moderately positive \\
\hline 25 & S+ & $0.14 \pm 0.01$ & moderately positive \\
\hline 26 & S+ & $1.00 \pm 0.12$ & highly positive \\
\hline 27 & S- & $0.18 \pm 0.13$ & moderately positive \\
\hline 28 & S+ & $0.16 \pm 0.30$ & moderately positive \\
\hline 29 & S- & $0.26 \pm 0.60$ & highly positive \\
\hline 30 & S+ & $0.14 \pm 0.02$ & moderately positive \\
\hline 31 & S- & $0.20 \pm 0.03$ & moderately positive \\
\hline 32 & S+ & $1.51 \pm 0.08$ & highly positive \\
\hline 33 & S+ & $0.41 \pm 0.09$ & highly positive \\
\hline 34 & S+ & $0.40 \pm 0.07$ & highly positive \\
\hline 35 & S+ & $0.27 \pm 0.06$ & highly positive \\
\hline 36 & S+ & $0.31 \pm 0.04$ & highly positive \\
\hline 37 & S+ & $0.23 \pm 0.02$ & highly positive \\
\hline 38 & S+ & $0.37 \pm 0.05$ & highly positive \\
\hline 39 & S- & $0.18 \pm 0.02$ & moderately positive \\
\hline 40 & S- & $0.16 \pm 0.03$ & moderately positive \\
\hline 41 & S- & $0.22 \pm 0.04$ & moderately positive \\
\hline 42 & S- & $0.25 \pm 0.05$ & highly positive \\
\hline 43 & S- & $0.12 \pm 0.03$ & moderately positive \\
\hline
\end{tabular}

isolates respectively harbored the $f n b A$ and $f n b B$ genes. The cna gene coding for adhesin to collagen was detected in 32 strains (74.4\%). Among the tested strains, 15 (34.9\%), 8 (18.6\%) and $13(30.2 \%)$ were positive for $\operatorname{ssp} A, \operatorname{ssp} B$ and geh genes.

\section{Statistical analysis \\ Association between Congo red phenotypic test and adherence assay}

Out of 20 highly-biofilm producing isolates, 18 showed a positive slime phenotype on Congo red agar. The nonparametric test of Mann Whitney U demonstrated that high biofilm production on polystyrene was significantly correlated with a positive Congo red phenotypic test $(p=0.017)$.

\section{Association between biofilm production on polystyrene and biofilm related genes}

Table 4 shows prevalence rates of MSCRAMMs genes ( fnbA, fnbB and $c n a$ ) and biofilm production control genes (icaA and icaD) depending on biofilm production. Univariate analysis followed by multivariate analysis showed that $f n b A$ and $f n b B$ genes were significantly associated with high biofilm production on polystyrene. However, no difference was observed in prevalence rates of icaA, icaD and cna genes between highly and moderately biofilm producing groups.

\section{Association between biofilm production on polystyrene and exoenzymes genes}

Table 5 details the prevalence rates of genes encoding serine protease $(\operatorname{ssp} A)$, cysteine protease $(s s p B)$ and lipase (geh) in moderate and high biofilm-producing groups. Analysis showed that the presence of $s s p B$ gene was significantly associated with high biofilm production on polystyrene $(\mathrm{p}=0.003)$. However, no differences were found in prevalence rates of $s s p A$ and geh genes between both groups (Table 5).

\section{Discussion}

S. aureus has emerged in recent decades as one of the leading causes of hospital and community infections [12]. Its virulence is a multifactorial process requiring the use of a variety of components regulated in a coordinated manner [2]. In this study, we noted that all isolates were alpha or beta-hemolytic. This finding agrees with the results of Barretti et al [13]. Hemolysin- $\alpha$ has pore-forming and pro-inflammatory properties. It binds to a membrane receptor and disrupts the integrity of host cells [14]. As for $\beta$-toxin, it is known to be the "hot-cold" hemolysin with a sphingomyelinase and a biofilm ligase activities [15-17].

Protease, lipase and lecithinase secretion were detected in most tested strains. Similar results were found by 
Table 4 Association between biofilm production on polystyrene and biofilm related genes

\begin{tabular}{llllll}
\hline Genes & & $\begin{array}{l}\text { Moderately bioflm } \\
\text { producers }(n=23)\end{array}$ & $\begin{array}{l}\text { Highly biofilm } \\
\text { producers }(n=20)\end{array}$ & $P$ (univariate analysis) & $P$ (multivariate analysis) \\
\hline MSCRAMMs genes & fnbA+ & $14 / 23$ & $18 / 20$ & $0,001^{\text {a }}$ & 0,040 \\
& fnbB+ & $2 / 23$ & $6 / 20$ & $0,002^{\text {a }}$ & 0,003 \\
& $c n a+$ & $15 / 23$ & $17 / 20$ & $0,154^{\text {a }}$ & 0,981 \\
Biofilm production control genes & $i c a A+$ & $13 / 23$ & $17 / 20$ & $0,143^{\text {a }}$ & 0,661 \\
& $i c a D+$ & $14 / 23$ & $13 / 20$ & 0,546 & - \\
\hline
\end{tabular}

a Factor studied in mutivariate analysis

many reports $[13,18,19]$. S. aureus uses proteolytic and lipolytic exoenzymes to invade, damage the host tissue components and even spread to other sites [20]. They also protect against the innate immune system and are key mediators of secreted and cell wall-associated virulence determinant stability [21].

Biofilm formation is a major virulence factor. It provides inter-bacterial contact, accumulation of bacteria in superimposed layers, protection against the host immunity and acquisition of significant multiresistance $[22,23]$. Our study showed that the majority of strains were slime producers on CRA. Several reports noted lower frequencies [13, 24-30]. In addition, all isolates were highly or moderately biofilm-forming on polystyrene. According to other studies, adhesion capacity was weaker $[1,4,9,10,27,28,31-34]$. This variability in adhesion capacity between MRSA strains can be explained by inter-strain variability of surface associated proteins and of biofilm production regulatory genes [23]. Significant association between biofilm production on polystyrene and Congo red test in our study highlights the performance of this non-costly phenotypic test to detect potential virulent $S$. aureus clinical isolates. Similarly, previous reports showed a high consistency between both tests [28, 30,31].

Biofilm formation in S. aureus isolates occurs through the polysaccharide intercellular adhesin (PIA) as well as the MSCRAMMs. These structures provide initial binding of S. aureus to host tissues and biomaterials [29]. After the step of adhesion and colonization of host cells and mucous membranes, a phase of tissue invasion occurs. It was demonstrated that fibronectin binding proteins FnbA and FnbB are involved in bacterial invasion of the endothelial cells in vivo and in vitro [35]. Prevalences of $f n b A$ and $f n b B$ genes were higher in other studies [36, 37]. Moreover, the intracellular adhesion (ica) operon is essential for the control of biofilm production. The synthesis of polymer matrix exopolysaccharides is monitored by the icaADBC operon, which encodes three membrane proteins (IcaA, IcaD, and IcaC) with enzymatic activity and one extracellular protein (IcaB). The PIA, encoded by this operon, plays also an important role in adhesion to epithelial cells and allows escaping the immune system of the host. Frequencies of icaA and icaD genes were also higher in several previous studies [4, 24, 26-28, 35, 37]. Our results showed that icaA and icaD genes were not present in all highly biofilm formers. This discrepancy between biofilm phenotype and genotype could be due to the fact that ica expression is dependent on environmental conditions [38].

Adhesion to collagen plays an important role in the pathogenesis induced by $S$. aureus [36]. The collagen binding protein Cna is the second most important adhesion molecule. Furthermore, the recombinant Cna can even be designed as an effective vaccine component and antibodies raised against $\mathrm{Cna}$ are protective in a mouse model of S. aureus induced septic death [39]. Most of studied isolates were positive for cna gene. Other reports revealed lower rates $[4,35,37,40]$.

The complexity of bacterial tools used for cell adherence and invasion ranges from single monomeric proteins to intricate multimeric macromolecules that perform highly sophisticated functions [41]. In contrast with this study, $s s p A, s s p B$ and geh genes were harbored by all strains of another report [40].

- With regard to the complexity and the variability of the biofilm phenotype, genetic studies identified numerous genes involved in biofilm formation.

Table 5 Association between biofilm production on polystyrene and exoenzymes genes

\begin{tabular}{lllll}
\hline Exoenzymes genes & Moderately bioflm producers $(n=23)$ & Highly biofilm producers $(n=20)$ & $P$ (univariate analysis) & $P$ (bivariate analysis) \\
\hline geh+ & $8 / 23$ & $5 / 20$ & 0,791 & - \\
sspA+ & $6 / 23$ & $9 / 20$ & $0,117^{\mathrm{a}}$ & 0,223 \\
sspB+ & $1 / 23$ & $5 / 20$ & $0,013^{\mathrm{a}}$ & 0,003 \\
\hline
\end{tabular}

${ }^{a}$ Factor studied in bivariate analysis 
However, their relative importance is still unclear [42]. In the light of this, our multivariate analysis showed that the presence of $f n b A$ and $f n b B$ genes was significantly associated with a high biofilm production on polystyrene. This consolidates the alleged role of these genes in biofilm formation. Comparably, some studies suggested that detection of some adhesion factors is more practical for the prediction of biofilm formation $[4,31,43]$. Other reports have shown the decisive role of the ica gene [32, 33]. However, no statistical difference was found in the distribution of genes by some researchs [28, 31]. Such investigations aim to find new attractive targets for antivirulence therapy by overcoming biofilm formation [31].

We also found a significant association between the presence of $\operatorname{ssp} B$ gene and biofilm production. In fact, a number of soluble extracellular proteins can affect biofilm formation. The relationship between staphylococcal enzymes activities and biofilm formation was reported by some studies. However, it remains to be elucidated and merits further investigation [44].

\section{Conclusion}

In summary, most of our MRSA isolates were highly biofilm producers with elevated prevalences of some MSCRAMMs genes and biofilm production control genes. The present study indicates that the detection of the adhesion factors ( $f n b A$ and $f n b B$ genes) contributing to the first step of biofilm formation can be used as a biofilm formation marker in $S$. aureus. Further in-depth research could be of value in the development of new preventive and therapeutic measures of staphylococcal infections.

\section{Abbreviations}

ATCC: American Type Culture Collection; Cna: Collagen binding protein; CRA: Congo red agar; DNA: Deoxyribonucleic acid; Fnb: Fibronectin binding protein; Ica: Intracellular adhesion; MRSA: Methicillin resistant Staphylococcus aureus; MSCRAMMs: Microbial Surface Components Recognizing Adhesive Matrix Molecules; OD: Optical density; PCR: Polymerase chain reaction; PIA: Polysaccharide intercellular adhesion; TSA: Trypticase soja agar

\section{Acknowledgements}

Not applicable.

\section{Funding}

This work was financed by the Higher education and scientific research in Tunisia through the laboratory of Transmissible Diseases and Biologically Active Substances, LR99ES27, Faculty of Pharmacy, Monastir University, street Avicenne 5000 Monastir (Tunisia).

\section{Availability of data and materials}

All data generated or analysed during this study are included in this published article.

\section{Authors' contributions}

$\mathrm{OH}, \mathrm{YK}$ and $\mathrm{MM}$ collected and cultured the strains. $\mathrm{OH}, \mathrm{AM}, \mathrm{AE}$ and $\mathrm{MM}$ designed the experiments. $\mathrm{OH}, \mathrm{AM}$ and $\mathrm{HR}$ carried out the experiments. $\mathrm{OH}$ and $\mathrm{AE}$ analyzed the data. $\mathrm{OH}, \mathrm{AM}$ and $\mathrm{MM}$ prepared the manuscript. All authors read and approved the final manuscript.

Ethics approval and consent to participate Not applicable.

\section{Consent for publication}

Not applicable.

\section{Competing interests}

The authors declare that they have no competing interests.

\section{Publisher's Note}

Springer Nature remains neutral with regard to jurisdictional claims in published maps and institutional affiliations.

Received: 6 April 2018 Accepted: 23 October 2018

Published online: 13 November 2018

\section{References}

1. Naicker PR, Karayem K, Hoek KG, Harvey J, Wasserman E. Biofilm formation in invasive Staphylococcus aureus isolates is associated with the clonal lineage. Microb Pathog. 2016;90:41-9 https://doi.org/10.1016/j.micpath.2015.10.023.

2. Dinges MM, Orwin PM, Schlievert PM. Exotoxins of Staphylococcus aureus. Clin Microbiol Rev. 2000;13:16-34.

3. Donlan RM. Biofilms: microbial life on surfaces. Emerg Infect Dis. 2002;8:88190 https://doi.org/10.3201/eid0809.020063.

4. Khoramian B, Jabalameli F, Niasari-Naslaji A, Taherikalani M, Emaneini M. Comparison of virulence factors and biofilm formation among Staphylococcus aureus strains isolated from human and bovine infections. Microb Pathog. 2015;88:73-7 https://doi.org/10.1016/j.micpath.2015.08.007.

5. Abraham NM, Jefferson KK. A low molecular weight component of serum inhibits biofilm formation in Staphylococcus aureus. Microb Pathog. 2010;49: 388-91 https://doi.org/10.1016/j.micpath.2010.07.005.

6. Dobinsky S, Kiel K, Rohde H, Bartscht K, Knobloch JK, Horstkotte MA, et al. Glucose-related dissociation between icaADBC transcription and biofilm expression by Staphylococcus epidermidis: evidence for an additional factor required for polysaccharide intercellular adhesin synthesis. J Bacteriol. 2003; 185:2879-86.

7. Milheiriço C, Oliveira DC, de Lencastre H. Multiplex PCR strategy for subtyping the staphylococcal cassette chromosome mec type IV in methicillin-resistant Staphylococcus aureus: 'SCCmec IV multiplex'. J Antimicrob Chemother. 2007:60:42-8 https://doi.org/10.1093/jac/dkm112.

8. Stulik L, Malafa S, Hudcova J, Rouha H, Henics BZ, Craven DE, et al. aHemolysin activity of methicillin-susceptible Staphylococcus aureus predicts ventilator-associated pneumonia. Am J Respir Crit Care Med. 2014;15:113948 https://doi.org/10.1164/rccm.201406-10120C.

9. Kouidhi B, Zmantar T, Hentati H, Bakhrouf A. Cell surface hydrophobicity, formation, adhesives properties and molecular detection of adhesins genes in Staphylococcus aureus associated to dental caries. Microb Pathog. 2010; 49:14-22 https://doi.org/10.1016/j.micpath.2010.03.007.

10. Manago K, Nishi J, Wakimoto N, Miyanohara H, Sarantuya J, et al. Biofilm formation by and accessory gene regulator typing of methicilin-resistant Staphylococcus aureus strains recovered from patient with nosocomial infections. Infect Control Hosp Epidemiol. 2006;27:188-90 https://doi.org/10. 1086/500620.

11. Stepanovic S, Vukovic D, Dakic I, Savic B, Svabic-Vlahovic M. A modified microtiter-plate test for quantification of staphylococcal biofilm formation. J Microbiol Methods. 2000:40:175-9.

12. Gould I. Costs of hospital-acquired methicillin-resistant Staphylococcus aureus (MRSA) and its control. Int J Antimicrob Agents. 2006;28:379-84 https://doi.org/10.1016/j.ijantimicag.2006.09.001.

13. Barretti P, Montelli AC, Batalha JE, Caramori JC, Cunha Mde L. The role of virulence factors in the outcome of staphylococcal peritonitis in CAPD patients. BMC Infect Dis. 2009:9(212) https://doi.org/10.1186/ 1471-2334-9-212 
14. Inoshima N, Wang Y, Wardenburg JB. Genetic requirement for ADAM10 in severe Staphylococcus aureus skin infection. J Invest Dermatol. 2012;132: 1513-6 https://doi.org/10.1038/jid.2011.

15. Salgado-Pabón W, Herrera A, Vu BG, Stach CS, Merriman JA, et al. Staphylococcus aureus $\beta$-toxin production is common in strains with the $\beta$ toxin gene inactivatedby bacteriophage. J Infect Dis. 2014;210:784-92 https://doi.org/10.1093/infdis/jiu146.

16. Diep BA, Carleton HA, Chang RF, Sensabaugh GF, Perdreau-Remington F. Roles of 34 virulence genes in the evolution of hospital- and communityassociated strains of methicillin-resistant Staphylococcus aureus. J Infect Dis. 2006;193:1495-503 https://doi.org/10.1086/503777.

17. Huseby MJ, Kruse AC, Digre J, et al. Beta toxin catalyzes formation of nucleoprotein matrix in staphylococcal biofilms. Proc Natl Acad Sci USA. 2010;107:14407-12 https://doi.org/10.1073/pnas.0911032107.

18. Wu PZ, Zhu H, Thakur A, Willcox MD. Comparison of potential pathogenic traits of staphylococci that may contribute to corneal ulceration and inflammation. Aust N Z J Ophthalmol. 1999;27:234-6.

19. Lakshmi HP, Prasad UV, Yeswanth S, Swarupa V, Prasad OH, Narasu ML, et al. Molecular characterization of a-amylase from Staphylococcus aureus. Bioinformation. 2013;9:281-5. https://doi.org/10.6026/97320630009281.

20. Kolar SL, Ibarra JA, Rivera FE, Mootz JM, Davenport JE, et al. Extracellular proteases are key mediators of Staphylococcus aureus virulence via the global modulation of virulence-determinant stability. Microbiologyopen. 2013;2:18-34 https://doi.org/10.1002/mbo3.55.

21. Donlan RM, Costerton JW. Biofilms: survival mechanisms of clinically relevant microorganisms. Clin Microbiol Rev. 2002;15:167-93.

22. Pozzi C, Waters E, Rudkin J, Schaeffer C, Lohan A, Tong P, et al. Methicillin Resistance Alters the Biofilm Phenotype and Attenuates Virulence in Staphylococcus aureus Device-Associated Infections. PLoS Pathog. 2012;8: 1002626 https://doi.org/10.1371/journal.ppat.1002626.

23. Mulcahy ME, Geoghegan JA, Monk IR, O'Keeffe KM, Walsh EJ, Foster TJ, et al. Nasal colonisation by Staphylococcus aureus depends upon clumping factor $\mathrm{B}$ binding to the squamous epithelial cell envelope protein loricrin. PLoS Pathog. 2012;8:1003092 https://doi.org/10.1371/journal.ppat.1003092.

24. El-Mahallawy HA, Loutfy SA, El-Wakil M, El-Al AK, Morcos H. Clinical implications of icaA and icaD genes in coagulase negative staphylococci and Staphylococcus aureus bacteremia in febrile neutropenic pediatric cancer patients. Pediatr Blood Cancer. 2009:52:824-8 https://doi.org/10.1002/pbc.21964.

25. Elkhatib WF, Khairalla AS, Ashour HM. Evaluation of Different Microtiter PlateBased Methods for the Quantitative Assessment of Staphylococcus aureus Biofilms. Future Microbiol. 2014;9:725-35 https://doi.org/10.2217/fmb.14.33.

26. Arciola CR, Baldassarri L, Montanaro L. Presence of icaA and icaD genes and slime production in a collection of staphylococcal strains from catheterassociated infections. J Clin Microbiol. 2001;39:2151-6 https://doi.org/10. 1128/JCM.39.6.2151-2156.2001.

27. Lindsay JA, Moore CE, Day NP, Peacock SJ, Witney AA, Stabler RA. Microarrays reveal that each of the ten dominant lineages of Staphylococcus aureus has a unique combination of surface-associated and regulatory genes. J Bacteriol. 2006:188:669-76 https://doi.org/10.1128/JB.188.2.669-676.2006.

28. Grinholc M, Wegrzyn G, Kurlenda J. Evaluation of biofilm production and prevalence of the icaD gene in methicillin-resistant and methicillinsusceptible Staphylococcus aureus strains isolated from patients with nosocomial infections and carriers. FEMS Immunol Med Microbiol. 2007:50: 375-9 https://doi.org/10.1111/j.1574-695X.2007.00262.x.

29. Jain A, Agarwal A. Biofilm production, a marker of pathogenic potential of colonizing and commensal staphylococci. J Microbiol Methods. 2009;76:8892. https://doi.org/10.1016/j.mimet.2008.09.017.

30. Arciola CR, Campoccia D, Baldassarri L, Donati ME, Pirini V, Gamberini S, et al. Detection of biofilm formation in Staphylococcus epidermidis from implant infections. Comparison of a PCR-method that recognizes the presence of ica genes with two classic phenotypic methods. J Biomed Mater Res A. 2006;76:425-30.

31. Cha JO, Yoo Jl, Yoo JS, Chung HS, Park SH, Kim HS, et al. Investigation of Biofilm Formation and its Association with the Molecular and Clinical Characteristics of Methicillin-resistant Staphylococcus aureus. Osong Public Health Res Perspect. 2013;4:225-32 https://doi.org/10.1016/.jphrp.2013.09.001.

32. Nourbakhsh F, Namvar AE. Detection of genes involved in biofilm formation in Staphylococcus aureus isolates. GMS Hyg Infect Control. 2016;22(11) https://doi.org/10.3205/dgkh000267.

33. Szczuka E, Urbańska K, Pietryka M, Kaznowski A. Biofilm density and detection of biofilm-producing genes in methicillin-resistant Staphylococcus aureus strains. Folia Microbiol. 2013;58:47-52 https://doi.org/10.1007/s12223012-0175-9.

34. Namvar AE, Asghari B, Ezzatifar F, Azizi G, Lari AR. Detection of the intercellular adhesion gene cluster (ica) in clinical Staphylococcus aureus isolates. GMS Hyg Infect Control. 2013;29(8) https://doi.org/10.3205/ dgkh000203.

35. Peacock S, Moore C, Justice A, Kantazanou M, Story L, Mackie K, et al. Virulent combinations of adhesin and toxin genes in natural populations of Staphyloccus aureus. Infect Immun. 2002;70:4987-96.

36. Arciola CR, Campoccia D, Gamberini S, Baldassarri L, Montanaro L. Prevalence of $\mathrm{cna}$, fnbA and fnbB adhesin genes among Staphylococcus aureus isolates from orthopedic infections associated to different types of implant. FEMS Microbiol Lett. 2005;246:81-6 https://doi.org/10.1016/j.femsle. 2005.03.035.

37. Rahimi F, Katouli M, Karimi S. Biofilm production among methicillin resistant Staphylococcus aureus strains isolated from catheterized patients with urinary tract infection. Microb Pathog. 2016;98:69-76 https://doi.org/10. 1016/j.micpath.2016.06.031

38. Zmantar T, Chaieb K, Makni H, Miladi H, Abdallah FB, Mahdouani K, et al. Detection by PCR of adhesins genes and slime production in clinical Staphylococcus aureus. J Basic Microbiol. 2018;48:308-14 https://doi.org/10. 1002/jobm.20070028.

39. Madani A, Garakani K, Mofrad MRK. Molecular mechanics of Staphylococcus aureus adhesin, CNA, and the inhibition of bacterial adhesion by stretching collagen. PLoS One. 2017;12:0179601 https://doi.org/10.1371/journal.pone. 0179601.

40. Karlsson A, Arvidson S. Variation in extracellular protease production among clinical isolates of Staphylococcus aureus due to different levels of expression of the protease repressor sarA. Infect Immun. 2002;70:4239-46.

41. Pizzaro-Cerda J, Cossart P. Bacterial adhesion and entry into host cells. Cell. 2006;124:715-27 https://doi.org/10.1016/j.cell.2006.02.012.

42. Tang J, Chen J, Li H, Zeng P, Li J. Characterization of adhesin genes, staphylococcal nuclease, hemolysis and biofilm formation among Staphylococcus aureus strains isolated from different sources. Foodborne Pathog Dis. 2013;10:757-63 https://doi.org/10.1089/fpd.2012.1474.

43. O'Neill E, Pozzi C, Houston P, Humphreys H, Robinson DA, Loughman A, et al. A novel Staphylococcus aureus biofilm phenotype mediated by the fibronectin-binding proteins, FnBPA and FnBPB. J Bacteriol. 2008;190:383550 https://doi.org/10.1128/JB.00167-08.

44. Mann EE, Rice KC, Boles BR, Endres JL, Ranjit D, Chandramohan L, et al. Modulation of eDNA release and degradation affects Staphylococcus aureus biofilm maturation. PLoS One. 2009;9:e5822 https://doi.org/10.1371/journal. pone.0005822

45. Saïd-Salim B, Dunman PM, McAleese FM, Macapagal D, Murphy E, McNamara PJ, et al. Global regulation of Staphylococcus aureus genes by Rot. J Bacteriol. 2003;185:610-9.

Ready to submit your research? Choose BMC and benefit from:

- fast, convenient online submission

- thorough peer review by experienced researchers in your field

- rapid publication on acceptance

- support for research data, including large and complex data types

- gold Open Access which fosters wider collaboration and increased citations

- maximum visibility for your research: over $100 \mathrm{M}$ website views per year

At $\mathrm{BMC}$, research is always in progress.

Learn more biomedcentral.com/submission 